\title{
WIP: Teaching a Knowledge Engineering Course Using Active Learning, Gamification, and Scaffolding
}

\section{Dr. Bruce R Maxim, University of Michigan, Dearborn}

Bruce R. Maxim has worked as a software engineer, project manager, professor, author, and consultant for more than thirty years. His research interests include software engineering, human computer interaction, game design, social media, artificial intelligence, and computer science education. Dr. Maxim is professor of computer and information science at the University of Michigan-Dearborn. He established the GAME Lab in the College of Engineering and Computer Science. He has published a number of papers on computer algorithm animation, game development, and engineering education. He is coauthor of bestselling introductory computer science and software engineering texts. Dr. Maxim has supervised several hundred industry-based software development projects as part of his work at UM-Dearborn.

\section{Dr. Gail Luera, University of Michigan-Dearborn}




\title{
WIP: Teaching a Knowledge Engineering Course Using Active Learning, Gamification, and Scaffolding
}

\begin{abstract}
This paper describes the authors' experiences introducing active learning opportunities in a senior level software analysis and design course. The team critically examined the existing artificial intelligence course offered at our institution and created new active learning style instructional materials for selected course topics. We devised delivery strategies that incorporated academic research findings and industry best practices. We focused on problembased learning strategies for this course, supported by software tools. Based on our assessment data, we believe that students participating in the activities created for this course are better equipped with fundamental theoretical knowledge and valuable hands-on experiences that can measurably increase their ability to contribute to the software industry. Both face to face and online students preferred active learning content delivery to lecture only. Both groups of students felt more engaged with the course materials than they do in traditional lecture courses.
\end{abstract}

\section{Background}

Many courses offered by the College of Engineering and Computer Science (CECS) rely heavily on lectures as the primary vehicle of instruction. This is even true of courses that emphasize student project work. In the lecture mode of instruction student engagement with the course material is often low or non-existent until the date of an assessment activity (assignment or exam) is near. Many computing (Computer Science (CS), Data Science (DS), Software Engineering (SE), Cybersecurity and Information Assurance (CIA)) students are turned off by this sterile delivery of material ${ }^{1}$. In passive learning environments students often do not get many opportunities to develop their soft skills.

Feedback from several employers indicate that our graduates have good communication and software engineering skills but are weak in their abilities to conceptualize problems in terms of artificial intelligence (AI) problem solving techniques. Even when students have been exposed to the prerequisite AI skills and concepts in their coursework, they were rarely asked to apply them in project settings. In a typical lecture/project course, the instructor can only cover a small number of AI techniques in 3 or 4 programming assignments. In the past, instructors (and employers) have relied on just-in-time learning to fill in these conceptual gaps when students begin to work on projects.

The purpose of this paper is to examine whether or not students feel engaged and confident in their ability to solve AI problems as a result of participating in problem-based learning activities. The activities created for this project are grounded in the research literature on student engagement. Flipped classroom style course delivery was used to provide students with opportunities to spend more time solving AI problems during the semester. With this style of instruction we are able to help students continue development of their soft skills. By adding gamification elements to the course, we allow students to customize their course participation. At the end of the course students who completed the face to face version of the course and students 
who completed the distance learning version of the course answered online survey questions about their perceptions of the effectiveness of the course activities and their personal levels of engagement with the course materials.

\section{Active Learning}

Several engineering educators regard experiential learning as the best way to train the next generation of engineers ${ }^{2}$. This requires engineering programs to go beyond offering industrybased capstone courses and internships. It is our belief that introducing students to active learning opportunities can improve software engineering education the undergraduate level. We believe this will also increase the pool of new professionals with practical AI problemsolving skills.

The materials created for this course were developed using a variation of the ADDIE (analyze, design, development, implementation, evaluation) process model. ${ }^{3}$ When new materials were created the team attempted to determine the best mix of case-study review, role-play, hands-on exercises involving work with AI algorithms, or work with AI tools to facilitate coverage of the topics. Many of the activities implemented in the courses have been used successfully with several groups of students. Their evolution benefited from feedback provided by the students, faculty.

There is consensus among members of our department's professional advisory board that professional practice invariably requires strong verbal and written communication skills. To develop their oral communications skills, students need opportunities to both make presentations and observe their peers presenting. Some instructors believe that the project activities inherent in real-world software development encourage students to improve their written and oral communication skills ${ }^{4}$. To this end, the investigators included small group problem solving activities with the expectation that students would provide written or oral summaries of the strategies used to attack their tasks and their lessons learned.

Active learning is "embodied in a learning environment where the teachers and students are actively engaged with the content through discussions, problem-solving, critical thinking, debate and a host of other activities that promote interaction among learners, instructors and the material" 5 . Prince defines active learning as a classroom activity that requires students to do something other than listen and take notes ${ }^{6}$. Active learning opportunities can complement or replace lectures to make class delivery more interesting to the students. In this project students wrote critical reviews of the assigned text material before coming to class. The instructor typically provided a short lecture overview of the concepts relevant to the day's activities. The majority of the class time was spent with students working in small groups to complete a problem solving or design task. The distance learning students created similar tasks on their own working at home.

Specifically, active learning helps students develop problem-solving, critical-reasoning, and analytical skills, all of which are valuable tools that prepare students to make better decisions, become better students and, ultimately, better employees ${ }^{6}$. Raju and Sankar undertook a study to develop teaching methodologies that could bring real-world issues into engineering classrooms ${ }^{7}$. 
The results of their research led to recommendations to engineering educators on the importance of developing interdisciplinary technical case studies that facilitate the communication of engineering innovations to students in the classroom.

Active learning helps students learn by increasing their involvement in the process ${ }^{8}$. Active learning techniques help students to better understand the topics covered in the curriculum ${ }^{9}$. Active learning helps students to be more excited about the study of engineering than traditional instruction ${ }^{1}$. The group work that often accompanies active learning instruction help students develop their soft skills and makes students more willing to meet with instructors outside of class $^{10}$. Krause writes that engagement does not guarantee learning is taking place, but learning can be enhanced if it provides students with opportunities to reflect on their learning activities ${ }^{11}$. In our project students are encouraged to reflect on the lessons learned from the activities in writing or in a class postmortem discussion.

Day and Foley used class time exclusively for exercises, by having their students prepare themselves through the study of materials provided online ${ }^{12}$. Bishop and Verleger presented a comprehensive survey of the research on different ways of using class exercises using a technique that is often referred to as the "flipped" classroom ${ }^{13}$. Wu et.al. effectively implemented class exercises as active learning tools in their flipped classroom approach ${ }^{14}$.

The active learning approach of problem-based learning (PBL) has been consistently demonstrated to lead to positive learning outcomes such as self-directed learning habits, problem-solving skills, and deep disciplinary knowledge while engaging students in collaborative, authentic learning situations ${ }^{15}$. While PBL was first incorporated into medical school curricula in 1969, it is currently used in a wide variety of courses ${ }^{16}$. For instance within the field of engineering, Warnock and Mohammadi-Aragh investigated the impact of PBL on student learning in a biomedical materials course and found that students made significant improvements in their problem-solving, communication and teamwork skill ${ }^{17}$. PBL has also been used in senior engineering courses with the same positive results ${ }^{18,19,20}$. Although students in a PBL software engineering course reported that the projects were more time intensive than a typical course project, they were receptive to the approach since they thought it was related to the professional environment and provided them with opportunities to relate theory and practice. This was in contrast to students taught using a traditional lecture and project approach to the course who viewed completing a traditional course project more negatively ${ }^{21}$. Given all of the positive evidence, it was determined that a PBL pedagogical approach was well suited for a senior level software project course.

\section{Student Engagement}

Active learning techniques such as Think-Pair-Share exercises ${ }^{22}$, pair programming ${ }^{23}$, peer instruction $^{24}$, and flipped classrooms ${ }^{25}$ have been demonstrated to increase student engagement. Many of these interventions are used at the introductory level, primarily to address broadening participation in large classes ${ }^{26}$.

Ham and Myers brought Process Oriented Guided Inquiry Learning (POGIL) into a computer organization course ${ }^{27}$. In software engineering courses, the use of real-world, community-based, 
projects is recognized as a good way to engage students with a meaningful problem while teaching them software engineering concepts ${ }^{28}$. Students often become more invested in their project when they see that their products are more than simply a paper design. In our course redesign we used the class activities to motivate students to design experiments or use an AI techniques to solve a real-world programming problem.

An important aspect of software engineering education is the development of soft skills such as communication and project management. There are a number of examples of courses that make use of project work to help students enhance their soft skills simultaneously with their software development skills ${ }^{29}$. Decker and Simkins ${ }^{30}$ introduced the use of an extended role play approach in a game development processes class where the students were not assessed solely on the artifacts they produced, but rather the processes by which they created the artifacts. Their roleplay activities emphasize industry best practices for both technical and soft skills (project management, communication, marketing, and interdisciplinary design). We included some roleplay activities in the course redesign.

\section{Gamified Learning}

Gamified learning or the gamification of learning has been defined as the use of game design elements in non-game settings in order to increase motivation and attention on a task ${ }^{31}$. James Gee has identified thirty-six learning principles that are present in good games ${ }^{32}$. These learning principles provide the backbone for good game design and, in turn, can be used as guiding principles when designing a gamified learning environment. For instance, good games provide players with information when they need it and within the context in which the information will be used ${ }^{33}$. Effective game design includes challenging players so they are routinely working at the edge of their abilities and knowledge, also known as their zone of proximal development ${ }^{31}$. Having students, or players, operate within this optimal learning zone helps keep them engaged and encourages them to learn more in order to meet the demands of the next challenge.

Gee contends that well designed games are motivational specifically because of the different learning principles outlined previously ${ }^{32}$. Working at the limits of their abilities keeps players engaged as they continue to take on new challenges ${ }^{34}$. Gee refers to this process as a cycle of expertise, which requires players to constantly learn, act, revise and learn again in order to demonstrate mastery and be successful in a game ${ }^{35}$.

Lee and Hammer suggest that the social and emotional aspects of rewards and consequences earned in gaming environments contribute to student motivation as well ${ }^{36}$. The key is finding a balance between the positive and negative outcomes so that players remain motivated to proceed and don't become overwhelmed or discouraged ${ }^{31}$. A well-designed game can also motivate players to stay engaged by enhancing the value of the task or tasks being completed ${ }^{37}$. This is particularly beneficial with educational games focused on school related subjects that students might not otherwise choose to immerse themselves within.

Allowing students to negotiate the nature of their activities and rewards up front often goes a long way to ensuring that all students are engaged for the entire semester. A light-weight gamification framework was created for CIS 479 and was used within the course to allow 
students to customize their course participation to some degree. Students were not required to do all out of class assignments or all textbook chapter critiques. This allowed the ability to spend more time on some tasks and less on others. It also gave students a means of making up lost points by doing more than the minimum assigned tasks.

\section{Course Description}

A senior level software project course, CIS 479 (Artificial Intelligence), offered by the Computer and Information Science (CIS) department is organized as a three credit-hour course. This course is taken by a majority of all computing majors in the CIS department (CS, SE, DS, and CIA). The course is offered both simultaneously as a hybrid face to face and online, distance learning course. The ABET student outcomes for CIS 479 appear in Table 1.

\section{Table 1: CIS 479 ABET Student Outcomes and Course Outcomes}

ABET Outcomes addressed in this course:

1. Analyze a complex computing problem and to apply principles of computing and other relevant disciplines to identify solutions.

2. Design, implement, and evaluate a computing-based solution to meet a given set of computing requirements in the context of the program's discipline

Course outcomes, the students will be able to:

1. The student will be able to describe common knowledge representation schemes

2. The student will be able to describe the architectures of machine learning systems and expert systems

3. The student will be able to design a state representation and a static evaluation function for an alpha-beta game algorithm

4. The student will be able to write a series of LISP functions

CIS 479 meets twice a week for three hours each class period for forty-two contact hours over a period of seven weeks. The topics covered in this course are listed in Table 2. Typically, this class has been taught as a lecture only class with students completing four programming assignments, two examinations, and one oral presentation. Distance learning students watch the course video for each class and complete class assignments on their own at home.

In this paper, we discuss the use of the group problem solving activities to replace most of the class time students previously spent listening to class lectures. Some group problem solving activities made use of scaffolding in the form of software tools to allow for student experimentation. All activities were adapted to allow individual distance learning students to complete them at home working alone. Many of the modules used in the revised course were developed as part of an internally funded curriculum redesign project. Exams were replaced with 
written critical reflections on the assigned text readings. Gamified learning principles were used to create some flexibility in completing the course requirements.

Table 2: CIS 479 Course Topics

\begin{tabular}{|l|c|}
\hline Topic & Hours \\
\hline Introduction to Artificial Intelligence & 1 \\
Common Lisp Programming & 4 \\
State Space Problem Representation & 1 \\
Heuristic Search & 3 \\
Adversarial Search and Game Opponents & 3 \\
Production Systems and Rule-based Programing & 2 \\
Expert Systems and Liability & 1 \\
Uncertainty and Probabilistic Reasoning & 3 \\
Decision Making & 3 \\
Knowledge Representation & 3 \\
Planning and Intelligent Agents & 3 \\
Genetic Algorithms & 3 \\
Neural Networks and Machine Learning & 3 \\
Student Presentations on AI and Social Responsibility & 3 \\
Reactive Game AI and Chatbots & 3 \\
Final Student Oral Presentation & 3 \\
\hline
\end{tabular}

\section{Course Delivery}

During Summer 2019, CIS 479 was taught using a flipped classroom model. Most of the six weekly contact hours were used for engaged problem-based learning. $20 \%$ of the total student grade was allocated to competition of these activities, $50 \%$ was allocated to out of class project assignments, $20 \%$ to two individual oral presentations, and $10 \%$ to graded reading reflections completed before each class period.

A gamification policy was used in which students were only required to do five of six project assignments, ten of eleven reading reflections, and ten of eleven active learning modules. Extra points earned in any of these three categories could be shifted to one of the other categories. Everyone was required to complete the two oral presentations.

Prior to coming to class students were expected to read the sections of the course textbook ${ }^{38}$ assigned for class that day. The lecture slides and class handouts were available on campus course management system (Canvas). If students had any questions prior to class they were encouraged to email, or meet with, the instructor and/or teaching assistants during their office hours. Most students read the text material and completed their reflections prior to coming class. 
Table 3: CIS 479 Course Modules

\begin{tabular}{|c|c|}
\hline Topic & Activity \\
\hline $\begin{array}{l}\text { Introduction to Artificial } \\
\text { Intelligence }\end{array}$ & $\begin{array}{ll}\text { - } & \text { Role play: Turing test - one student pretends to be } \\
\text { computer with script, one student } \\
\text { - } \\
\text { Role play: Naïve human plays tic-tac-toe against human } \\
\text { using rule-base algorithm }\end{array}$ \\
\hline $\begin{array}{l}\text { State Space Problem } \\
\text { Representation }\end{array}$ & $\begin{array}{l}\text { - Students form small groups and work out the details of } \\
\text { representing the states and transitions using post it notes }\end{array}$ \\
\hline Heuristic Search & $\begin{array}{l}\text { - Student groups make use of heuristic search to develop } \\
\text { a paper prototype solution to the } 2 \text { disk } 3 \text { peg version of } \\
\text { the Towers of Hanoi problem }\end{array}$ \\
\hline $\begin{array}{l}\text { Adversarial Search and } \\
\text { Game Opponents }\end{array}$ & $\begin{array}{l}\text { Student groups create a game state representation, } \\
\text { prototype move generator, and static evaluation function } \\
\text { to be used with mini max to play a simple game }\end{array}$ \\
\hline $\begin{array}{l}\text { Production Systems and } \\
\text { Rule-based Programing }\end{array}$ & $\begin{array}{l}\text { - Class members use roleplay to simulate the rule } \\
\text { selection and conflict resolutions strategies used in a } \\
\text { rule-based system that solves the problem of bagging } \\
\text { groceries }\end{array}$ \\
\hline $\begin{array}{l}\text { Uncertainty and Probabilistic } \\
\text { Reasoning }\end{array}$ & $\begin{array}{l}\text { - Students groups solve several Bayes Theorem problems } \\
\text { and share their results with the class }\end{array}$ \\
\hline Decision Making & $\begin{array}{l}\text { Student groups create a decision tree, decision table, and } \\
\text { a set of heuristic rules to select the best heuristic search } \\
\text { algorithm based on problem characteristics }\end{array}$ \\
\hline Knowledge Representation & $\begin{array}{l}\text { - Students create a sematic network to show relationship } \\
\text { in the song I’m My Own Grandpa } \\
\text { - Student pairs create a frame for a restaurant } \\
\text { - Student groups create a bank robbery script }\end{array}$ \\
\hline $\begin{array}{l}\text { Planning and Intelligent } \\
\text { Agents }\end{array}$ & $\begin{array}{l}\text { - Student pairs create and test a plan for making a peanut } \\
\text { butter sandwich } \\
\text { - Student pairs work with to create and simulate the } \\
\text { behavior of mean ends/GPS to solve a simplified } \\
\text { version of the monkey, box, stick, and banana problem }\end{array}$ \\
\hline Genetic Algorithms & $\begin{array}{l}\text { - Student groups use dice to simulate the behavior of a } \\
\text { genetic algorithm to solve the knapsack problem }\end{array}$ \\
\hline $\begin{array}{l}\text { Neural Networks and } \\
\text { Machine Learning }\end{array}$ & $\begin{array}{l}\text { - Student groups conduct experiment involving } \\
\text { reinforcement learning to teach a simulated computer to } \\
\text { play Hexpawn }\end{array}$ \\
\hline
\end{tabular}

The project assignments completed out of class included creating a program that focused on pattern matching in Lisp, a knowledge engineering task requiring the creation of a rule-based expert system, and several experiments. One experiment involved writing a program that allowed students to compare the differences in performance when using $\mathrm{A}^{*}$ or Branch and Bound to solve a puzzle problem. A second experiment involved using a tool created for this course to explore the effects of various conditions on the mini-max algorithm used by a game AI with and 
without alpha beta pruning. A third involved creating a library of tools to experiment with genetic algorithm parameters to generate the solution to a problem. A fourth involved creating and programming an AI game agent and comparing its performance to that of several default agents.

\section{Assessment}

Each of these course assignments is evaluated by Canvas rubrics designed by the instructor for each type of submission. Currently, these rubrics contain five to ten criteria scored 1 to 5 for each. Table 4 shows the rubrics used to evaluate AI programming assignments in both 2017 and 2019. Additional rubrics were created in 2019 to reflect the changing nature of the assignments in 2019. Table 5 shows the rubric used in 2019 to evaluate assignments that called for students to conduct experiments. We use these new rubrics as the primary means of assessing student learning in the 2019 course.

Table 4: CIS 479 Programming Assignment Rubric

\begin{tabular}{|l|l|}
\hline \multicolumn{1}{|c|}{ Topic } & $\begin{array}{c}\text { Rating and Feedback } \\
(\mathbf{0}=\text { missing, } \mathbf{4}=\text { satisfactory, } \mathbf{5}=\mathbf{e x c e e d s} \text { specification })\end{array}$ \\
\hline External document -Questions & \\
\hline Listing and Compilation & \\
\hline Sample Run (test case coverage) & \\
\hline Style - Use of AI Tools & \\
\hline Program Comments & \\
\hline
\end{tabular}

Table 5: CIS 479 Experiment Assignment Rubric

\begin{tabular}{|l|c|}
\hline \multicolumn{1}{|c|}{ Topic } & $\begin{array}{c}\text { Rating and Feedback } \\
(\mathbf{0}=\text { missing, } \mathbf{4}=\text { satisfactory, 5=exceeds specification })\end{array}$ \\
\hline Introduction - Problem Statement & \\
\hline Procedure (including code) & \\
\hline Results (with graphs and tables) & \\
\hline Discussion & \\
\hline Conclusions & \\
\hline
\end{tabular}

No statistical comparisons were made between student performance in the active learning delivery of the CIS 479 and a lecture-based delivery of CIS 479, since topic coverage has changed as well as course delivery. However, informal comparisons of student data from the two such offerings of CIS 479 delivered by the instructor suggest that the active learning students produced work which seemed to receive higher scores using similar grading rubrics. There were no apparent differences between the performances of the face to face students and the distance learning students. Three different instructors teach CIS 479, three times a year at our institution, which make statistical comparisons between treatments difficult.

Students on our campus complete a standard set of course evaluations at the end of the semester. The evaluation form is completed online and anonymously, prior to receiving their final course 
grades. Summer 2017 was that last time the instructor taught CIS 479 using lectures as the primary method of course delivery. Summer 2019 was the first time the instructor used active learning and problem based small group exercises as the primary method of instructional delivery. The average student response values were comparable for the two instructional methods. Table 5 shows the means scores for the two face to face sections and Table 6 shows the mean scores for the two distance learning sections. We are not sure why there was a slight drop between 2017 and 2019 in the average evaluation scores for three questions for the face to face students. There is a possibility that students were expecting more concrete coverage of programming algorithm details than is typically found in many AI textbooks. The overall course rating is slightly higher in 2019 for both the face to face and distance learning sections of the active learning version of the course.

Table 5: Selected Course Assessment Questions Lecture vs Active Learning

\begin{tabular}{|c|c|c|}
\hline $\begin{array}{c}\text { CIS } 479-\text { Face to Face } \\
1=\text { strongly disagree, } 5=\text { strongly agree }\end{array}$ & $\begin{array}{l}\text { Summer } 2017 \\
\quad \mathrm{~N}=\mathbf{9} / \mathbf{1 6}\end{array}$ & $\begin{array}{c}\text { Summer } 2019 \\
\quad N=18 / 31\end{array}$ \\
\hline Course fulfilled my needs & 4.3 & 4.3 \\
\hline Course objectives were clear & 4.6 & 4.4 \\
\hline Course was challenging and interesting & 4.8 & 4.5 \\
\hline Course never repeats other course material & 4.3 & 4.2 \\
\hline Overall course rating & 4.4 & 4.8 \\
\hline
\end{tabular}

Table 6: Selected Course Assessment Questions Lecture vs Active Learning

\begin{tabular}{|c|c|c|}
\hline $\begin{array}{c}\text { CIS } 479 \text { - Distance Learning } \\
1 \text { = strongly disagree, } 5 \text { = strongly agree }\end{array}$ & $\begin{array}{c}\text { Summer } 2017 \\
\quad N=5 / 14\end{array}$ & $\begin{array}{c}\text { Summer } 2019 \\
N=7 / 14\end{array}$ \\
\hline Course fulfilled my needs & 4.6 & 4.6 \\
\hline Course objectives were clear & 4.6 & 4.7 \\
\hline Course was challenging and interesting & 4.4 & 4.6 \\
\hline Course never repeats other course material & 4.6 & 4.6 \\
\hline Overall course rating & 4.6 & 4.7 \\
\hline
\end{tabular}

We also surveyed the students at the end of the Summer 2019 semester to check student perceptions of their classroom engagement. The students in both sections of CIS 479 were asked to a set of online survey questions created by the authors that have used to assess several active learning classes in the past. Students completed this survey anonymously, before knowing their final courses grades. This survey was conducted separately form the regular student course evaluations. The survey findings appear in Tables 7 and 8. It is interesting to note that the response rates for the active learning and engagement survey was higher than for the standard student course evaluation questions shown in Tables 5 and 6. 
Table 7: Student Perceptions of Active Learning and Engagement

\begin{tabular}{|c|c|c|c|c|c|}
\hline \multicolumn{6}{|c|}{ CIS 479 - Artificial Intelligence Face-To-Face - Summer 2019 (N=30/31) } \\
\hline Survey Statement & $\begin{array}{l}\text { Strongly } \\
\text { Disagree }\end{array}$ & Disagree & Neutral & Agree & $\begin{array}{c}\text { Strongly } \\
\text { Agree }\end{array}$ \\
\hline $\begin{array}{l}\text { Course activities were } \\
\text { useful way to learn }\end{array}$ & $2 \quad(7 \%)$ & 0 & 0 & $10(33 \%)$ & $18(60 \%)$ \\
\hline $\begin{array}{c}\text { Course activites let me } \\
\text { apply what I learned }\end{array}$ & $2 \quad(7 \%)$ & 0 & $1(3 \%)$ & $8(27 \%)$ & $19(63 \%)$ \\
\hline $\begin{array}{c}\text { Course is an example of } \\
\text { active learning }\end{array}$ & $3 \quad(10 \%)$ & 0 & 1 (3\%) & $9(30 \%)$ & $16(53 \%)$ \\
\hline $\begin{array}{l}\text { I was actively engaged } \\
\text { in my learning }\end{array}$ & $3 \quad(10 \%)$ & 0 & $5(16 \%)$ & $10(33 \%)$ & $13(43 \%)$ \\
\hline $\begin{array}{l}\text { I applied the course } \\
\text { material to real world } \\
\text { situations }\end{array}$ & $1 \quad(3 \%)$ & $2 \quad(7 \%)$ & $8(27 \%)$ & $11(37 \%)$ & $8(27 \%)$ \\
\hline $\begin{array}{l}\text { I felt more engaged } \\
\text { during activities than } \\
\text { lecture }\end{array}$ & 2 (7\%) & $2 \quad(7 \%)$ & 1 (3\%) & $9(30 \%)$ & $16(53 \%)$ \\
\hline $\begin{array}{c}\text { I prefer use of } \\
\text { activitieis and } \\
\text { discussion to lecture } \\
\text { only content }\end{array}$ & $2 \quad(7 \%)$ & 0 & $2(7 \%)$ & $4(13 \%)$ & $22(73 \%)$ \\
\hline
\end{tabular}

Table 8: Student Perceptions of Active Learning and Engagement

\begin{tabular}{|c|c|l|l|l|l|}
\hline \multicolumn{6}{|c|}{ CIS 479 - Artificial Intelligence Distance Learning - Summer 2019 (N=14/14) } \\
\hline Survey Statement & $\begin{array}{c}\text { Strongly } \\
\text { Disagree }\end{array}$ & Disagree & Neutral & Agree & $\begin{array}{c}\text { Strongly } \\
\text { Agree }\end{array}$ \\
\hline $\begin{array}{c}\text { Course activities were } \\
\text { useful way to learn }\end{array}$ & 0 & 0 & 0 & $7(50 \%)$ & $7(50 \%)$ \\
\hline $\begin{array}{c}\text { Course activites let me } \\
\text { apply what I learned }\end{array}$ & 0 & 0 & 0 & $3(21 \%)$ & $11(79 \%)$ \\
\hline $\begin{array}{c}\text { Course is an example of } \\
\text { active learning }\end{array}$ & 0 & 0 & 0 & $4(29 \%)$ & $10(71 \%)$ \\
\hline $\begin{array}{c}\text { I was actively engaged } \\
\text { in my learning }\end{array}$ & 0 & 0 & $4(29 \%)$ & $3(21 \%)$ & $7(50 \%)$ \\
\hline $\begin{array}{c}\text { I applied the course } \\
\text { material to real world } \\
\text { situations }\end{array}$ & 0 & 0 & $5(36 \%)$ & $5(36 \%)$ & $4(29 \%)$ \\
\hline $\begin{array}{c}\text { I felt more engaged } \\
\text { during activities than } \\
\text { lecture }\end{array}$ & 0 & 0 & $1(7 \%)$ & $3(21 \%)$ & $10(71 \%)$ \\
\hline $\begin{array}{c}\text { I prefer use of activities } \\
\text { and discussion to } \\
\text { lecture only content }\end{array}$ & 0 & 0 & $41 \%)$ \\
\hline
\end{tabular}




\section{Lessons Learned}

The student comments on the course evaluations indicated that they enjoyed the problem solving activities and felt these activities helped them when creating their project deliverables. They also felt that sharing ideas and insights with other students during class discussions helped them learn. They enjoyed being able to apply the material covered in the textbook to solve actual problems. Some students felt that not all activities matched the textbook topics as well as they could have.

Students appreciated the problems solving modules for a variety of reasons. They felt these activities were more engaging than just listening to a lecture accompanied by slides. The students liked the redundancy that was built in the activities that often had them look at different facets of similar problems. Some students wrote that they felt the group work and subsequent presentation summaries helped them become more at ease when speaking in class.

Students felt that the strengths of this course were the dynamic learning activities, the lack of exams, and the programs assigned as homework. Some students felt the reading assignments were spaced a little close together in their due dates. They also felt that focusing on application problems collaboratively provides a better opportunity for students to learn the material. They felt, that completing the hands on activities provides students with better backgrounds for collaborative problem solving.

\section{Future Direction}

We were encouraged by the enthusiasm that students exhibited while working with the active learning modules and look forward to continuing to develop this course content. Experience from the summer 2019 course delivery of CIS 479 is being used to revise the next offering of this course and the corresponding active learning materials. We will try to find activities which better match the course topics. The current plan is to make use of the revised modules in the summer 2020 offering of CIS 479 which will be fully online due to the decision to close down all face to face classes in response to the Covid19 pandemic. We are continuing to develop software tools to provide scaffolding assistance for student experiments. It may also be desirable to add some course elements to reward students for coming to class with the assigned readings completed when face to face classes return in the future.

\section{Acknowledgments}

This project was partially supported by a University of Michigan-Dearborn Advancement of Teaching and Learning Fund Grant and a University of Michigan-Dearborn Henry W. Patton Center for Engineering Education and Practice, Engineering Education Research Seed Grant. We would like to thank Ms. Adriana Haddad and Mr. Phillip Klein who created the software tools developed for this project.

\section{Bibliography}

1. Maxim, B. R.; Decker, A.; and Yackley, J. J. (2019) "Student Engagement in Active Learning Software Engineering Courses”, Proceedings of 49th IEEE Annual Frontiers in Education Conference, Cincinnati, OH, 
October 2019 (F3G1-F3G5).

2. Samavedham, L. and Ragupathi, K. (2012) “Facilitating 21st century skills in engineering students," The Journal of Engineering Education, Vol. XXVI No. 1, 2012, pp.38-49.

3. Branch R. (2010): Instructional Design: The ADDIE Approach, Springer, 2010.

4. Ardis, M., Chenoweth, S. and Young, F. (2008): “The 'Soft' Topics in Software Engineering Education”, Proceedings of 38th Annual Frontiers in Education Conference (Vol. 1, Oct 2008), IEEE Press, Saratoga Springs, NY, 2008, pp. F3H1-F3H6.

5. Promoting Active Learning (2016), https://utah.instructure.com/courses/148446/pages/active-learning, retrieved February 25, 2016.

6. Prince, M., (2004): “Does Active Learning Work? A Review of the Research”, Journal of Engineering Education, Vol. 93, 2004, pp. 223-231.

7. Raju, P. K. and Sanker, C. C. (2013) “Teaching real-world issues through case studies,” Journal of Engineering Education. Vol. 88 No 4 pp501-508.

8. Nickels, K, M. (2000) "Do's and don'ts of introducing active learning techniques,” Proceedings of the 2000 Annual Meeting of the American Society for Engineering Education, St. Louis, Missouri, June 2000.

9. Wood, K.; Jensen, D.; Dutson, A.; and Green, M. (2003) “Active learning approaches in engineering design courses," Proceedings of the 2003 Annual Meeting of the American Society for Engineering Education, Nashville, Tennessee, June 2003.

10. Meier, R. D. (1999) “Active learning in large lectures,” Proceedings of the 1999 Annual Meeting of the American Society for Engineering Education, Charlotte, North Carolina, June 1999.

11. Krause, R.; Hayton, A. C.; Wonoprabowo, J.; and Loo, L.; (2017) "Is engagement alone sufficient to ensure "active learning?", Loma Linda University Student Journal, Vol. 2 No. 1, 2017.

12. Day, J.A., and Foley J.D. (2006): "Evaluating a Web Lecture Intervention in a Human-Computer Interaction Course”, IEEE Transactions on Education 49(4):420-431, 2006.

13. Bishop, J.L. \& Verleger M.A. (2013): “The Flipped Classroom: A Survey of the Research”, ASEE 120th Annual Conference and Exposition, Atlanta, GA.

14. Wu, P., Manohar, P., and Acharya, S. (2016): "The Design and Evaluation of Class Exercises as Active Learning Tools in Software Verification and Validation”, Information Systems Education Journal.

15. Savery, J. and Duffy, T. (1995). "Problem-based learning: An instructional model and its constructivist framework,” Educational Technology, Vol. 35, No. 5, 1995, pp.31-38.

16. Silva, A., Bispo, A., Rodriguez, D. and Vasquez, F. (2018), "Problem-based learning: A proposal for structuring PBL and its implications for learning among students in an undergraduate management degree program", Revista de Gestão, Vol. 25, No. 2, 2018, pp. 160-177.

17. James N. Warnock \& M. Jean Mohammadi-Aragh (2016) Case study: use of problem-based learning to develop students' technical and professional skills, European Journal of Engineering Education, Vol. 41, No, 2, 2016, pp.142-153,

18. Dunlap, J. (2005). "Problem-based learning and self-efficacy: How a capstone course prepares students for a profession.” Education Technology Research and Development Vol. 53, No.1, 2005, pp. 65-83.

19. Urbanic, R. (2011). "Developing design and management skills for senior industrial engineering students.” Journal of Learning Design, Vol. 4, No. 3, 2011, pp. 35-49.

20. Gavin, K. 2011. "Case study of a project-based learning course in civil engineering design.” European Journal of Engineering Education Vol., 36, No. 6, 2011, pp. 547-558.

21. Souza, M, Moreira, R. and Figueiredo (2019). "Students perception on the use of project-based learning in software engineering education”, SBES 2019: Proceedings of the XXXIII Brazilian Symposium on Software Engineering, 2019, pp. 537-546.

22. Kothiyal, A.; Majumdar, R.; Murthy, S.; and Iyer, S. (2013) "Effect of think-pair-share in a large CS1 class: 83\% sustained engagement,” In Proceedings of the ninth annual international ACM conference on International computing education research (ICER '13). ACM, New York, NY, USA, 2013, pp. 137-144. DOI: https://doi.org/10.1145/2493394.2493408

23. Nagappan, N.; Williams, L.; Ferzli, M.; Wiebe, E,; Yang, K.; Miller, C.; and Balik, S. (2003) "Improving the CS1 experience with pair programming," In Proceedings of the 34th SIGCSE technical symposium on Computer science education (SIGCSE '03). ACM, New York, NY, USA, 2003, pp. 359-362. DOI: 
https://doi.org/10.1145/611892.612006

24. Porter, L.; Bouvier, D.; Cutts, Q.; Grissom, S,; Lee, C.; McCartney, R.; Zingaro, D.; and Simon, B. (2016) “A multi-institutional study of peer instruction in introductory computing," In Proceedings of the 47th ACM Technical Symposium on Computing Science Education (SIGCSE '16). ACM, New York, NY, USA, 2016, pp. 358-363. DOI: https://doi.org/10.1145/2839509.2844642

25. Greer, T.; Hao, Q.; Jing, M.; and Barnes, B. (2019) “On the effects of active learning environments in computing education," In Proceedings of the 50th ACM Technical Symposium on Computer Science Education (SIGCSE '19), February 27-March 2, 2019, Minneapolis, MN, USA. ACM, New York, NY, USA, 6 pages. https://doi.org/10.1145/3287324.3287345

26. Hoffman, B.; Morelli, R.; and Rosato, J. (2019) "Student engagement is key to broadening participation in CS," In Proceedings of the 50th ACM Technical Symposium on Computer Science Education (SIGCSE '19), February 27-March 2, 2019, Minneapolis, MN, USA. ACM, New York, NY, USA, 7 pages. https://doi.org/10.1145/3287324.328743

27. Ham, Y. and Myers, B. (2019) "Supporting guided onquiry with cooperative learning in computer organization,” In Proceedings of the 50th ACM Technical Symposium on Computer Science Education (SIGCSE '19). ACM, New York, NY, USA, 2019, pp. 273-279.

28. Stone, J. A. and Madigan, E. (2011) "Experiences with community-based projects for computing majors," Journal of Computer. Science in the Colleges, Vol. 26, No.6, June, 2011, pp.64-70.

29. Kharitonova, Y.; Luo, Y..; and Park, J. (2019) "Redesigning a software development course as a preparation for a capstone," An Experience Report. In Proceedings of the 50th ACM Technical Symposium on Computer Science Education (SIGCSE '19), February 27-March 2, 2019, Minneapolis, MN, USA. ACM, New York, NY, USA, 7 pages. https://doi.org/10.1145/3287324.3287498

30. Decker, A. and Simkins, D. (2016) "Leveraging role play to explore the software and game development process,” Proceedings of 46th IEEE Annual Frontiers in Education Conference, Erie, PA, October 2016, pp. S3F6-S3F10.

31. Saenz-de-Navarrete, J.; de-Marcos, L, Fernández-Sanz, L.; Pagés, C. A.; and Martínez-Herráiz, J. J. (2013) "Gamifying learning experiences: Practical implications and outcomes," Computers \& Education, Vol. 65, 2013, pp. 380-392.

32. Gee, J. P. (2014) What Video Games Have to Teach Us About Learning and Literacy, Second Edition. St. Martin’s Press, 2014.

33. Vygotsky, L. S. (1978) Mind and society: The development of higher mental processes, Harvard University Press, 1978.

34. Ott, M. and Tavella, M. (2009) "A contribution to the understanding of what makes young students genuinely engaged in computer-based learning tasks," Procedia - Social and Behavioral Sciences, Vol. 1 No. 1, 2009, pp. 184-188.

35. Gee, J. P. (2003) "What video games have to teach us about learning and literacy," Computers in Entertainment, Vol. 1, No. 1, October 2003, pp.1-4.

36. Lee, J. J. and Hammer, J. (2011) "Gamification in education: what, how, why bother? Definitions and uses," Exchange Organizational Behavior Teaching Journal, Vol. 15 No. 2, 2011, pp.1-5.

37. Yang, Y. T. C. (2012) "Building virtual cities, inspiring intelligent citizens: Digital games for developing students' problem solving and learning motivation,” Computers and Education, Vol. 59 No. 2, 2012, pp. 365377.

38. Russell, S. and Norvig, P. (2010): Artificial Intelligence: A Modern Approach, Prentice Hall, 2010. 